\title{
The Implementation of the Right to Asylum in Italy
}

\author{
Bruno Nascimbene
}

(C) ERA 2011

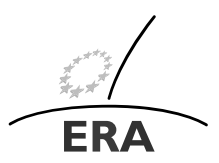

EUROPÄISCHE RECHTSAKADEMIE ACADEMY OF EUROPEAN LAW ACADEMIE DE DROIT EUROPEEN ACCADEMIA DI DIRITTO EUROPEO

\begin{abstract}
The issue of asylum has a variety of interesting aspects, both from an international and from a national perspective. The right to asylum is enshrined in the Italian Constitution. However, its implementation has not been easy for a number of reasons. In particular, the identification of the applicable law and the interpretation of the purpose of relevant legal provisions have not always been easy tasks. However analysis of the national experience allows for the development of some reflections on the scope of this institution, as it emerges from the interaction of the multiple legal sources that are today mutually involved in its functioning and are thus contributing to reshape it.
\end{abstract}

Keywords Asylum $\cdot$ Refugee status $\cdot$ Italy $\cdot$ Geneva Convention $\cdot$ EU law

\section{Asylum and Refugee Status in Italian Law}

Pursuant to Article 10 para. 3 of the Italian Constitution, the right to asylum is guaranteed "in accordance with the requirements laid down by the law" if foreigners are denied the effective exercise of democratic freedoms guaranteed by the same Constitution in their country. It applies even if foreigners are prosecuted for political crimes, thus preventing their extradition. This provision, however, has never been implemented by the adoption of a comprehensive law regulating the right to asylum and this has caused many difficulties of interpretation for courts and legal scholars. The

I take this opportunity to thank Dr. Alessia Di Pascale for her significant and relevant contribution to the drafting and editing of this article.

Prof. B. Nascimbene, Professor of European Union Law ( $\varangle)$

Faculty of Law, University of Milan, Milan, Italy

e-mail: b.nascimbene@unimi.it 
rule provides, in fact, for an absolute reservation of regulation by law and is closely connected not only with para. 2 of the same Article, which states that the status of foreigners (whom we can refer to as "ordinary" in comparison with the "special" condition of refugee) can only be regulated by the law, but also with para. 4 on the prohibition of extradition.

Para. 4 (as emerges from the travaux préparatoires of the Constitution) is a corollary of para. 3, although it does not exclusively protect beneficiaries of the right of asylum, given the broad wording of the rule. Para. 4 is also connected with Article 6 para. 2 of the Constitution, which prohibits the extradition of a citizen (which "under no circumstances can be permitted for political crimes"). ${ }^{1}$

A comparison between Article 10 para. 3 and the Geneva Convention confirms the broad scope of the constitutional rule: unlike the milestone provision constituted by Article 1A of the Geneva Convention, the right to asylum is recognised in fact for anyone who comes from a country that denies fundamental freedoms, regardless of whether (and hence of any proof that) the alien has been persecuted, or fears of being persecuted in the event of return.

The rule recognises a subjective right which can be claimed before the court, since it is an individual's right to obtain a declaratory ruling on that status: it is not only a right to apply, but it is also a right to be granted asylum when the specified conditions are met, even in the absence of a law governing the exercise of that right.

Numerous bills have been filed over time in order to bridge the legislative gap and implement the constitutional stipulation, but a comprehensive law on asylum has failed to be adopted. Such attempts have, nevertheless, caused some "confusion" between the right to seek and enjoy asylum and the right to seek and obtain refugee status or, more simply, between asylum and refugee status.

The so-called Martelli $\mathrm{Law}^{2}$ is emblematic in this respect: the title refers to political asylum, but the preamble and content of Article 1 refer to "refugees" (i.e., the class of people covered by the Geneva Convention). Moreover the implementing regulation established a so-called "Central Commission" responsible for determining the recognition of "refugee status". Subsequent legislative amendments brought by the so-called Bossi-Fini $\mathrm{Law}^{3}$ and a new implementing regulation have confirmed this approach. The Commission has become the central national Commission "for the right to asylum" and territorial commissions have been established for the recognition of refugee status. Relevant rules refer indifferently either to asylum and refugees, the implementing regulation even defining the "applicant for asylum" as the foreigner applying for the recognition of refugee status under the Geneva Convention and "asylum application" as the demand for recognition of that status. The law implementing the so-called "procedures" directive ${ }^{4}$ has kept the name and powers of the National

\footnotetext{
${ }^{1}$ Regarding the preparatory work, the link between par. 3 and 4 (the guarantees granted to political exiles are reinforced by expressly prohibiting the extradition) and the proposal made in favour of an additional paragraph on the right to asylum (clarifying that "extradition for political crimes is not admitted"), see Cassese [6], p. 544 ss. In relation to the right to asylum in Italy, see Benvenuti [2], Bonetti [4], Caligiuri [5], Chieffi [7] and [8], D'Orazio [10] and [11], Luciani [15], Nascimbene [18], Neri [21], Ziotti [23].

${ }^{2}$ Law of 28 February 1990 no. 39 that converted into law the Law decree of 30.12.1989, no. 416.

${ }^{3}$ Law of 30 July 2002, no. 189.

${ }^{4}$ Legislative Decree of 28 January 2008, no. 25.
} 
Commission "for the right of asylum" (in particular for withdrawal and termination of the status and the protection), but has renamed the Local Commissions, that are now competent "for the recognition of international protection".

None of these rules, however, has ever made or now makes reference to Article 10 para. 3 of the Constitution. The sole reference to this can be found in the Law on ratification and implementation of the Schengen agreements. Article 17 para. 2 states that the provisions of the Convention implementing the Schengen Agreements (of 14.6.1985) relating to applications for asylum and asylum seekers do not exclude the obligation of the competent national authorities to examine an asylum application submitted under Article 10 of the Constitution as implemented by legislation in force. Our country has availed itself of the opportunity granted by Article 29 para. 4 of the Convention ("each Party retains the right") to process an application for asylum even if the responsibility for so doing lies with another Contracting Party, for special reasons connected in particular with national law. This provision confirms the extensive protection afforded by Article 10 compared to other rules of our legal system. ${ }^{5}$

The argument put forward in the past, that asylum under Article 10 para. 3 is a genus that has different specifications, appears today fully substantiated and has received confirmation by case-law. ${ }^{6}$ The Geneva Convention would indeed be one of these specifications. This concerns, more precisely, the Law on the ratification of the Geneva Convention and Law 39/90, which amended the rules of adaption by shutting down both the effects of the declaration of the geographical limitation on the applicability to European citizens (the 1 January 1951 time limit had already been removed by the Law on ratification and implementation of the New York Protocol of 31 January 1967) and the reservations relating to employment and self-employment activities (Articles 17 and 18 of the Convention, accepted as simple recommendations). In practice, Italy had repeatedly derogated from the reservations, giving full implementation to the Convention. ${ }^{7}$

\footnotetext{
${ }^{5}$ This possibility was recognised by EC Regulation no. 343/2003 (the so-called "Dublin Regulation" of 18 February 2003, which provides most succinctly that in spite of jurisdiction criteria laid down in Chapter III of the Regulation each Member State may examine an application for asylum lodged with it by a third-country national, even if such examination is not its responsibility under the criteria laid down in the Regulation). The Schengen acquis, in accordance with Protocol (no. 2) (annexed at Amsterdam to the Treaty on the European Union and the Treaty establishing the European Community, and relating to the integration of Schengen into the framework of the European Union) was "applied immediately" to the Member States (under Article 2 of the Schengen Protocol, which took effect from 1 May 1999, the date of entry into force of the Amsterdam Treaty). Protocol (no. 29) on asylum for nationals of Member States provided for exceptional circumstances where a Member State might take into consideration applications for asylum made by a national of another Member States, as they are regarded as constituting safe countries of origin; this means that States' power of processing and deciding is not affected. Belgium made a statement (Statement no. 6) affirming that it would nevertheless examine European Union citizens' applications. The Italian government could indeed have made the same declaration, in line with art. 17, paragraph 2.

${ }^{6}$ See Consiglio di Stato (Council of State), IV, 11.7.2002, no. 3874 and the remarks in Nascimbene [19], p. 86 and Taglienti [22].

${ }^{7}$ See the remarks in Nascimbene [20], p. 115 ss.; among the most famous cases of exemption, it is worth recalling the asylum granted to about a thousand Chileans who fled to the Italian Embassy in Santiago and about thirty-five hundred citizens of Southeast Asia (Cambodians, Laotians, South Vietnams). On the measures taken in emergency situations, as a result of the influx of Albanian citizens, and citizens of the former Yugoslavia, as well as Somali citizens see Nascimbene [19], p. 6 s. and in particular the chapters therein by Pedrazzi and Trucco, p. 95 ss.
} 
With regard to the protection of fundamental rights such as the right of asylum, Article 10 , para. 1 is also likely to be relevant. This provision states that "the Italian legal system conforms to the generally recognised norms of international law", thus highlighting that protection by generally recognised norms of international law is a parameter of reference that cannot be disregarded. The Constitutional Court has applied this provision in relation to the right to health and the prohibition of discrimination against foreigners. ${ }^{8}$ This statement about the prohibition of discrimination should apply, a fortiori, for those who are refugees or asylum seekers.

The Court, comparing the "ordinary" alien to asylum seekers in accordance with Article 10 para. 3 has admitted the condition of reciprocity ("it is reasonable") in the case of a foreigner wishing to carry out the profession of journalist, but not for foreigners who are nationals of a State that does not guarantee the effective exercise of democratic freedoms, and therefore the most prominent manifestations of this, such as the freedom guaranteed by Article 21 of the Constitution. According to the Court, the assumption of reciprocity might indeed imply a serious "impairment of the freedom of those persons to whom the Constitution - Article 10 para. 3 - wanted to offer political asylum and who are entitled to enjoy at least in Italy all those fundamental democratic rights that are not closely related to the status civitatis". 9

\section{The Substance of the Right to Asylum Under Italian Law}

In the absence of a comprehensive law on asylum, another issue of greater importance for the implementation of the right to asylum has affected the significance of the constitutional provision and the identification of the competent court.

The prescriptive, not programmatic, nature of Article 10 para. 3 and the jurisdiction of ordinary rather than administrative courts were affirmed for the first time in a ruling delivered by the Supreme Court as late as $1997 .{ }^{10}$ This ruling has recognised a different, although dated, orientation, taken by some administrative courts and legal authors, which considered the right to asylum to be a perfect right. However, the Court's view that the contents of the right would be limited to the right of entry into the State, whereas only acknowledged refugees would benefit from the status provided by the Geneva Convention, cannot be shared. The Court's view that the contents of the individual right would be limited to the right of entry into the State cannot be shared, however, since in this case only acknowledged refugees would benefit from the status provided by the Geneva Convention. Further, this view is not correct, because the right of entry (corresponding to a negative prohibition of refoulement) certainly also includes those rights arising from instruments of humanitarian law and affecting life, dignity and treatment of a person, since any inhuman or de-

\footnotetext{
${ }^{8}$ Decision 30.7.2008, no. 306.

${ }^{9}$ Constitutional Court, 23.3.1968, no. 11 .

${ }^{10}$ Corte di Cassazione, 26.5.1997, no. 4674.
} 
grading treatment or torture are prohibited. Therefore, foreigners ought at least to be guaranteed a temporary stay so that they can rely on those essential rights that international and internal standards recognise. ${ }^{11}$

The orientation in favour of a subjective right was subsequently reaffirmed by the Supreme Court. In a later case the question of whether the jurisdiction of either the ordinary or administrative courts was in question came into relief. Assessment of jurisdiction depended on whether the qualification of asylum was considered as a subjective right or a legitimate interest, also in the light of both the changes brought by the Consolidated Text on immigration to Law 39/90 and the norms of transposition of EU rules that protect individuals' rights. ${ }^{12}$

In the long path of case-law that has accompanied the definition of the right to asylum, it is worth recalling what the forerunner of the current orientation was. In a decision issued by the Milan Court in $1964,{ }^{13}$ maximum importance was placed on humanitarian reasons in acknowledging the refugee status of those who at that time did not benefit from the protection of the Convention, since the geographical reservation had not been withdrawn by Italy yet. These people were in principle only entitled to UNHCR protection (i.e., constituting so-called de facto refugees) and were issued with a temporary residence permit while waiting to emigrate to another country. The Court affirmed that the practice of denying refugee status to those who could fall within the category of beneficiaries of Article 10 para. 3, rather than the Geneva Convention, was unsatisfactory and indeed contrary to this rule. It was emphasised that the right to asylum should be granted whenever it results from any "situation" or "circumstances of the fact that the effective exercise of democratic freedoms guaranteed by our Constitution [was] denied."

The humanitarian approach, however, has prevailed in more recent times, together with a proper evaluation of relevant international instruments, the case-law of the European Court of Human Rights and the views of legal scholars. In the famous Öçalan case (which concerned the leader of the Kurdistan Workers' Party PKK), the Rome court (Tribunale) acknowledged the right of asylum, assessing the effective violation of various democratic freedoms recognised by the Italian Constitution in Turkey. ${ }^{14}$

The Consolidated Text on Immigration has brought some important innovations in this regard. The abrogation of the provision which assigned jurisdiction to the administrative court to decide on the refusal of refugee status, but also the assertion

\footnotetext{
${ }^{11}$ See the remarks by Gaja [13] who wished that only ordinary courts would have jurisdiction both in relation to the right of asylum and refugee status. (At that time an administrative body had been entrusted to rule on asylum applications - the Central Commission established by Presidential Decree no. 136/1990.) See also Lenzerini [14] and Nascimbene [16].

${ }^{12}$ The most recent decisions issued by the Corte di Cassazione (Joint Sections) are no. 27310 of 17.11.2008, in Diritto immigrazione e cittadinanza, n. 1, 2009, p. 127, with a commentary by M. Acierno [1]; no. 11535 of 19.5.2009 in www.cortedicassazione.it/notizie/GiurisprudenzaCivile/ SezioniUnite; no. 19393 of 9.9.2009, in Guida al diritto, no. 41, 2009, p. 86, with a commentary by M. Piselli. See also the remarks in D'Ascia [9].

${ }^{13}$ Milan Court of Appeal, 27.11.1964, in Foro italiano, 1965, II, 122.

${ }^{14}$ Court (Tribunale) of Rome, 1.10. 1999, in Diritto immigrazione e cittadinanza, 1999, n. 3, p. 101 ss. (with an explanatory note).
} 
of jurisdiction of ordinary courts to decide on expulsion orders (except in the case of expulsions ordered by the Minister), has "consolidated" the jurisdiction of ordinary courts in recognising the right of asylum. It has been held, therefore, that "all disputes concerning the status of persons fall within the jurisdiction of the ordinary courts" and that the measures in the field "are of purely declaratory and not constitutive nature". ${ }^{15}$ The ordinary courts have jurisdiction concerning the right of asylum and international protection defined by European Union standards (and implementation rules), as well as on the humanitarian protection that the Local Commissions may recognise in the absence of the conditions that allow the international protection. ${ }^{16}$

\section{The Impact of European Union Law}

It can be affirmed that European Union law and national rules of transposition have significantly contributed to reshape the status of refugee and state obligations.

\subsection{The Qualification Directive}

In relation to the first point it is worth mentioning the recent case-law on the burden of proof concerning the conditions required for formal recognition. It must be noted in this regard that the criteria laid down by the Qualification Directive (2004/83) and the relevant decree of implementation (251/2007) are based on the credibility of those seeking international protection and on the real opportunity to provide any evidence required, the duty of the court (and before that of the territorial commission) being that of cooperating in the assessment of conditions and the enhancement of ex officio powers of investigation. The authority considering the application is assigned an "active and integrative role" in the inquiry, "free from ordinary civil procedural principles and foreclosures and impediments". 17 The court has broad powers: "due diligence" and "good faith" of the applicant are regarded as "elements of integration in the context of insufficient evidence with a clear upheaval of the ordinary rules on the burden of proof". This statement is based on European Union rules and the principle of consistent interpretation of national law. The Qualification Directive, and relevant criteria, should have been applied even before the expiry of the Directive's

\footnotetext{
${ }^{15}$ See Cassazione Joint Sections 17.12.1999, no. 907 that has confirmed Corte di Cassazione, Joint Sections no. 4674/1997 (this latter had been issued before the adoption of the Consolidated Text on Immigration, effected through Legislative Decree of 25 July 1998, no. 286). Article 47 of the Consolidated Text has repealed Article 5; Article 13 of the Consolidated Text established the jurisdiction, on the matter of expulsion, of the ordinary courts, since Article 47 abrogated Articles 2 ss. of the Martelli Law (which provided for the jurisdiction of the administrative courts).

${ }^{16}$ With regard to the requirements for the issuance of the permit of stay for humanitarian reasons (Art. 32, Legislative Decree no. 25/2008, Art. 5 Legislative Decree no. 286/98), see Corte di Cassazione no. 11535/2009; Consiglio di Stato, VI, 18.9.2009, no. 5619. Recent decisions have wanted to justify the different previous bias in favour of the jurisdiction of administrative courts. See also Bonetti [3].

${ }^{17}$ See Corte di Cassazione no. 27310/2008.
} 
term of transposition, given the unconditional nature of the content and accuracy of the rules on evidence. This principle (according to the case-law of the European Court of Justice mentioned by the court) should have led to a different determination instead of applying domestic law "so as to produce a result contrary to that sought by the Directive" and (therefore) to European Union law, which eventually also affects the national procedural law. ${ }^{18}$

\subsection{Push-backs to Libya}

The episodes and stances on the push-backs to Libya at sea carried out by Italian authorities in recent years have raised new profiles of interest about state obligations. The European Commission has sought an explanation from the Italian Government, recognising the value, in general, of the principle of non refoulement, the obligation to guarantee fundamental rights, to meet its international commitments under the Geneva Convention and the ECHR, as well as obligations deriving from European Union law. While not expressly reiterated, a breach of those obligations (regardless of the political significance of the dispute) could lead to the initiation by the Commission of an infringement procedure under Article 226 EC Treaty. ${ }^{19}$

The right to asylum, but also merely the possibility of applying must be guaranteed, in accordance with those rules of international law which are referred to in the agreements concluded between Italy and Libya, particularly in the Treaty of "friendship, partnership and cooperation" of 30 August 2008. Article 1 para. 6 expressly refers to the principles and generally accepted rules of international law and the Universal Declaration of Human Rights. International commitments would be compounded by law, the Consolidated Text on Immigration reaffirming the binding nature of the guarantee of fundamental rights (Article 2, paragraph 1) and prohibiting refoulement. This does not merely apply in the case of political asylum, refugee status, measures of temporary protection for humanitarian reasons (Art. 10 para. 4) and in all cases where international protection is necessary, in a broad sense, but even when the expulsion or refusal may expose the alien to risk of persecution, whether in the State to which they are rejected or returned, or in another State to which they are sent back.

The set of duties to be observed, mainly international and European Union obligations, gives a significant protection to the right of asylum.

\footnotetext{
${ }^{18}$ Corte di Cassazione no. 27310/2008. The decision on the merits was annulled because evidence of witnesses required in the second degree was not considered admissible, and the application for the recognition of refugee status had been refused, considering inadequate the statements made by the applicant (an Iraqi citizen of Kurdish origin and Shiite Muslim religion) in relation to religion and belonging to the Kurdish minority despite the proven knowledge of the Kurdish language. He had been rejected also the application for asylum pursuant to Art. 10 par. 3 and the request to issue a humanitarian permit.

${ }^{19}$ See the remarks made by the former Vice-President of the European Commission M. Barrot and by B. Nascimbene [17], referring to possible violations of European Union laws, such as the Reception Conditions Directive and the Schengen Border Code (adopted by regulation no. 62/2006 of 15 March 2006). See also Di Pascale [12].
} 


\section{Standards of Treatment}

The different combination of rules and, therefore, state obligations to protect individual rights provokes some reflections on refugee status, especially on the standards of treatment laid down by international and European Union standards.

\subsection{Geneva Convention Standards}

In principle (given their particular condition), refugees enjoy more favourable treatment than that provided for a so-called 'ordinary' foreigner. The Geneva Convention lays down different standards of treatment depending on the rights which are in question (although States may apply more favourable provisions to refugees). These standards refer to (a) the treatment accorded to nationals; (b) most-favoured-nation treatment; and (c) treatment no less favourable than that accorded to aliens generally in the same conditions.

The first standard of treatment is that accorded to nationals. The rights so guaranteed by the Convention, on an equal basis as the citizen, concern freedom of religion, protection of industrial and intellectual property, access to courts, rationing of products where there is shortage of supply, primary education, health and social security (with some exceptions), taxes (under Articles 4, 14, 16, 20, 22 para. 1, 23, 24, 29 para. 1). The second standard of treatment is the most favourable treatment accorded to nationals of a foreign country. The rights guaranteed are the rights of association and to engage in wage earning employment (Articles 15 and 17 para. 1). The third standard of treatment is the treatment provided to foreigners in general. It is the least favourable of the three, although derogating from this standard in a negative manner is not permitted. This applies to property rights, the exercise of self-employment and liberal professions, access to housing, secondary education and the freedom of movement (Articles 13, 18, 19, 21, 22 para. 2, 26).

There are no standards of treatment for personal status. The Convention contains a uniform rule of conflict that does not provide for the application of the law of the country of origin, but rather the application of the law of the domicile or, failing that, of the country of residence (Article 12). There are no standards, but most facilities in the field of administrative assistance, issuance of identity and travel papers, transfer of property, naturalisation (Articles 25, 27, 28, 34).

\subsection{European Union Standards}

As mentioned above, the Geneva Convention remains a cornerstone of European Union law. The latter law, however, has a wider scope, because it ensures subsidiary protection and applies to matters not covered by the Convention such as family reunification.

Unless otherwise stated, the Directive (Articles 20-34) grants to the beneficiaries of subsidiary protection, the same treatment as that accorded to refugees. Examples of where this approach is diverged from include regarding the duration of the permit of stay (which is shorter although still not less than one year) and the issuance of travel documents (which are not international, but national, and are released when 
the persons concerned cannot obtain a passport from their country). This diversity is reflected in the national transposition rules, since the permit granted to refugees has a duration of five years while that for subsidiary protection has a three years duration (see Article 23 of the Legislative Decree, and Article 24 of the Qualification Directive). With regard to family reunification (see Article 22 of the Legislative Decree, and Articles 2 and 23 Qualification Directive), the national transposing rule seems to apply a restrictive definition of 'family', merely enabling the beneficiaries of subsidiary protection to be reunited with their spouse and minor children rather than with adult children and parents (dependent), as is provided for refugees and foreigners in general (see Articles 29 and 29 bis of the Consolidated Text on Immigration). ${ }^{20}$ This appears to involve a lack of regulatory coordination, as there is no valid reason to treat the beneficiaries of subsidiary protection worse not only than refugees, but also than foreigners.

The categories of protected family members should therefore be four, without any distinction. ${ }^{21}$ No distinction should also be made regarding the status of unaccompanied minors, since the interests of the child must always be secured. ${ }^{22}$

\footnotetext{
${ }^{20}$ Article 29 on family reunification clarifies the scope of family members and Article 29bis regulates "family reunification of refugees" recalling Article 29. Article 29, most recently amended by Legislative Decree of 3 October 2008, no. 160 (which in turn amended the Decree no. 5 of 1.8.2007 implementing Directive $2003 / 86$ on family reunification) includes two categories of family members who are not covered by the Qualifications Decree. Article 2 defines the beneficiaries: dependent adult children "who, for objective reasons cannot provide for their essential needs of life because of their state of health leading to total disability"; dependent parents "if they have no other children in the country of origin or provenance or they are older than sixty five years and their other children are unable to support them for documented serious health problems". Moreover, Article 2 refers generically to a spouse, while Article 29 (as amended by Legislative Decree no. 160/08) refers to the spouse not legally separated and aged under eighteen. With respect to minors, Article 2 refers to "minor unmarried and dependent on the international protection's beneficiary", equating natural, adopted, fostered or under custody children to legitimate children, while Article 29 also applies to the unmarried children "of the spouse or born out of wedlock, provided that the other parent", if alive, has given his/her consent. Article 22 of the Qualifications Decree refers to Articles 29 and 29 bis in relation to aliens eligible for subsidiary protection, while Article 2 does not contain any reference to the definition of family members of beneficiaries, both of subsidiary protection and refugee status. The Qualification Directive, however, allows for the extension of the sphere of family members, leaving the States to decide whether to include beneficiaries other than the spouse and minor children (Articles 2, 23).

${ }^{21}$ It can be argued (as stated in the previous note) that even if in transposing the Qualification Directive, Italy has not made explicit the extension permitted by the Directive, such extension applies under the Consolidated Text on Immigration. We recall, again, that while, for the recognition of refugee status, the availability of accommodation and an annual income is not taken into account (because this is expressly provided by Article 29bis par. 2 and Article 29 para. 3), nothing is stated in relation to subsidiary protection beneficiaries whose rights are recognised pursuant to and under the terms stipulated in Article 29 (as provided by Article 22 para. 4 Qualifications Decree). Such differential treatment would be incongruous, even if the Directive permitted (see Article 23 para. 2) a variety of benefits: an adequate standard of living for families, without distinctions being made between categories of subjects, should be ensured.

${ }^{22}$ The Qualification Directive (Article 30) and the Decree of transposition (Article 28) do not operate any distinction, but the Consolidated Text on Immigration regulates only the case of minor refugees who are entitled to be reunited with their direct ascendants of the first degree (Article 29bis para. 3): the treatment should be considered applicable to the minor who benefits from subsidiary protection as well.
} 


\subsection{Varying Standards in Different Areas}

The Geneva Convention and European Union law (and implementing legislation) act together in defining standards, with a result that may coincide or vary depending on the subject matter. Equal treatment under European Union law (and therefore more favourable treatment compared to international law) is required for the exercise of employment and self-employment, registration in professional registries, vocational training and professional development (Article 25 Legislative Decree). An exception is access to public employment, because the standard is the same as that applied to European Union citizens, and beneficiaries of subsidiary protection are excluded (and equated to "ordinary" foreigners). The standard required by the Geneva Convention was adopted by European Union law and by implementing legislation in respect of (a) access to education (Article 26 Legislative Decree) (distinguishing between primary (for children) and general and secondary education (for adults): national treatment applies to the first case, while in the second case it is the treatment reserved to foreigners); (b) health and social care (Article 27 Legislative Decree), for which national treatment is provided; (c) free movement, integration and housing (Article 29 Legislative Decree) where, given the reference to the standards set by the Single Text on immigration, the treatment of foreigners is applied.

\subsection{Conclusion}

A comprehensive evaluation of the standards of treatment, in the light of their adaptation to European Union law, leads to positive conclusions, essentially for two reasons. The first reason concerns the extension of the range of beneficiaries. International protection guarantees rights not only to beneficiaries of refugee status, but also to the beneficiaries of subsidiary protection. The content of these rights as well as their extent is the same, except as otherwise stated by the Directive, and Member States are left the discretion to apply more favourable treatment to the beneficiaries of subsidiary protection and therefore the same treatment as refugees (Articles 3, 20 Directive). ${ }^{23}$

The second reason for being positive concerns the standard of treatment. National treatment, as was mentioned earlier (by virtue of the Geneva Convention and European Union law) is in fact the rule in relation to employment (except as regards the public service), self-employment, social security and health care, access to primary education, recognition of diplomas, certificates and other foreign titles. Due (solely)

\footnotetext{
${ }^{23}$ The Qualification Directive provides for distinct treatment of subsidiary protection beneficiaries in relation to residence permit (Article 24) and travel documents (Article 25). Such treatment may provide for different benefits relating to family members, but States must ensure that such benefits guarantee an adequate standard of living (Article 23). Insofar as regards access to employment and self employment, training for adults, vocational training and apprenticeship, states are left some discretion, whereas national treatment applies to refugees (Article 26). Health care, unlike for refugees, may be limited to essential services (Article 29), but states may grant access to integration programmes to subsidiary protection beneficiaries as well (Article 33). In the last three cases (under Articles 26, 29 and 33 of the Directive), the Italian system, as stated in the text, provides for the most favourable equality of treatment.
} 
to the Geneva Convention, national treatment is also the rule with regard to the freedom of religion, the protection of intellectual and industrial property, access to courts and taxation. ${ }^{24}$

The treatment of foreigners is the rule in relation to secondary education, freedom of movement in the State, access to housing, access to integration. By virtue (solely) of the Geneva Convention, national treatment is applied regarding property rights (namely purchasing and leasing of movable and immovable property). ${ }^{25}$

Regardless of the subject matter, refugee status deserves a special protection. More favourable treatment is therefore always justified under domestic law (and in our legal system in particular) compared to that provided by international and European Union law.

Hopefully, in the years to come Italian courts will provide a broad and comprehensive interpretation of Article 10, thus confirming that this provision expresses a concept embracing all the various manifestations of the need to seek protection in Italy for all those who do not enjoy fundamental rights or are subjected to possible attacks on these rights.

\section{References}

1. Acierno, M.: Il riconoscimento dello status di rifugiato politico: il procedimento e l'onere della prova al vaglio delle Sezioni Unite della Cassazione. Diritto immigrazione e cittadinanza (1), 79-86 (2009)

2. Benvenuti, M.: Il diritto d'asilo nell'ordinamento costituzionale. Un'introduzione. Cedam, Padova (2007)

3. Bonetti, P.: Il diritto d'asilo in Italia dopo l'attuazione della direttiva comunitaria sulle qualifiche e sugli status di rifugiato e di protezione sussidiaria. Diritto immigrazione e cittadinanza (1), 13-53 (2008)

4. Bonetti, P.: Profili generali e costituzionali del diritto d'asilo nell'ordinamento italiano. In: Nascimbene, B. (ed.) Diritto degli stranieri, pp. 1134-1168. Cedam, Padova (2004)

5. Caligiuri, A.: Art. 10, $3^{\circ}$ co. In: Bifulco, R., Celotto, A., Olivetti, M. (eds.) La Costituzione Italiana, pp. 253-261. Utet, Torino (2007)

6. Cassese, A.: Commento art. 10. In: Branca, G. (ed.) Commentario alla Costituzione. Zanichelli, Bologna (1975)

7. Chieffi, L.: La tutela costituzionale del diritto di asilo e di rifugio a fini umanitari. Diritto immigrazione e cittadinanza (2), 25-48 (2004)

8. Chieffi, L.: La tutela costituzionale del diritto di asilo e di rifugio a fini umanitari. In: M. Revenga Sánchez (ed.) I problemi costituzionali dell'immigrazione in Italia e Spagna, pp. 173-210. Valencia (2005)

9. D’Ascia, L.: Diritto degli stranieri e immigrazione. Giuffrè, Milano (2009)

10. D’Orazio, G.: (Asilo (diritto di) - II) Diritto costituzionale. In: Enciclopedia giuridica, Roma, vol. III (1991)

11. D’Orazio, G.: Condizione dello straniero e "società democratica". Cedam, Padova (1994)

12. Di Pascale, A.: Control at sea: the Italian case. In: Mitsilegas, V., Ryan, B. (eds.) Extraterritorial Immigration Control: Legal Challenges, pp. 281-302. Brill, Leiden (2010)

13. Gaja, G.: Diritto dei rifugiati e giurisdizione ordinaria. Rivista di diritto internazionale 791-792 (1997)

\footnotetext{
${ }^{24}$ See Articles 4, 14, 16, 29 of the Geneva Convention.

${ }^{25}$ See Article 13 of the Geneva Convention; the most-favoured nation clause is applied in relation to "rights of association" (Article 15, which refers to non-political and non-profit-making associations and to trade unions).
} 
14. Lenzerini, F.: The evolution of Italian jurisprudence concerning the relationship between the constitutional right of asylum and the recognition of refugee status. In: Italian Yearbook of International Law, vol. XIX, pp. 139-156 (2009)

15. Luciani, M.: Cittadini e stranieri come titolari di diritti fondamentali. Rivista critica di diritto privato 203-251 (1992)

16. Nascimbene, B.: Comments on the past ten years of italian jurisprudence on the right of asylum. In: Italian Yearbook of International Law, vol. XIX, pp. 159-162 (2009)

17. Nascimbene, B.: Control of illegal immigration and Italian-EU relations, IAI Documents. Available on http://www.iai.it/pdf/DocIAI/IAI0922E.pdf

18. Nascimbene, B.: Die italienische Einwanderungs-und Asylpolitik - völkerrechtliche, europarechtliche und verfassungsrechtliche Aspekte - die aktuelle Reformdiskussion - die jüngsten Umsetzungsmaßnahmen. In: Hilpold, P., Perathoner, C. (eds.) Immigration und Integration. Völkerrechtliche und europarechtliche Antworten auf eine zentrale Herausforderung der Zeit, pp. 205-235. Peter Lang, Frankfurt am Main (2010)

19. Nascimbene, B.: La condizione giuridica dello straniero. Cedam, Padova (1997)

20. Nascimbene, B.: Lo straniero nel diritto italiano, Appendice di aggiornamento. Giuffré, Milano (1990)

21. Neri, L.: Profili sostanziali:lo status di rifugiato. In: Nascimbene, B. (ed.) Diritto degli stranieri, pp. 1134-1215. Cedam, Padova (2004)

22. Taglienti, C.: Diritto d'asilo e status di rifugiato nell'ordinamento italiano. Available on http://www. giustiziaamministrativa.it/documentazione/studi_contributi/diritto_asilo.hml

23. Ziotti, L.: Il diritto d'asilo nell'ordinamento costituzionale italiano. Un'introduzione. Cedam, Padova (1988) 